University of Nebraska - Lincoln

DigitalCommons@University of Nebraska - Lincoln

Faculty Publications: Department of Entomology

Entomology, Department of

$5-2006$

\title{
Microbial decomposition of skeletal muscle tissue (Ovis aries) in a sandy loam soil at different temperatures
}

David O. Carter

University of Nebraska-Lincoln, dcarter2@unl.edu

Mark Tibbett

University of Western Australia, Mark.Tibbett@uwa.edu.au

Follow this and additional works at: https://digitalcommons.unl.edu/entomologyfacpub

Part of the Entomology Commons

Carter, David O. and Tibbett, Mark, "Microbial decomposition of skeletal muscle tissue (Ovis aries) in a sandy loam soil at different temperatures" (2006). Faculty Publications: Department of Entomology. 288. https://digitalcommons.unl.edu/entomologyfacpub/288

This Article is brought to you for free and open access by the Entomology, Department of at DigitalCommons@University of Nebraska - Lincoln. It has been accepted for inclusion in Faculty Publications: Department of Entomology by an authorized administrator of DigitalCommons@University of Nebraska - Lincoln. 


\title{
Microbial decomposition of skeletal muscle tissue (Ovis aries) in a sandy loam soil at different temperatures
}

\author{
David O. Carter and Mark Tibbett \\ Centre for Land Rehabilitation, School of Earth and Geographical Sciences, \\ University of Western Australia, Crawley, WA 6009, Australia \\ Corresponding author - M. Tibbett, tel 6186488 2635, fax 6186488 1050, email mark.tibbett@uwa.edu.au \\ Present address for D. O. Carter - Department of Plant Pathology, University of Nebraska-Lincoln, \\ 406 Plant Sciences Hall, Lincoln, NE 68583-0722, USA; dcarter2@unl.edu
}

\begin{abstract}
A laboratory experiment was conducted to determine the effect of temperature $\left(2,12,22{ }^{\circ} \mathrm{C}\right)$ on the rate of aerobic decomposition of skeletal muscle tissue (Ovis aries) in a sandy loam soil incubated for a period of 42 days. Measurements of decomposition processes included skeletal muscle tissue mass loss, carbon dioxide $\left(\mathrm{CO}_{2}\right)$ evolution, microbial biomass, soil $\mathrm{pH}$, skeletal muscle tissue carbon $(\mathrm{C})$ and nitrogen $(\mathrm{N})$ content and the calculation of metabolic quotient $\left(\mathrm{qCO}_{2}\right)$. Incubation temperature and skeletal muscle tissue quality had a significant effect on all of the measured process rates with $2{ }^{\circ} \mathrm{C}$ usually much lower than 12 and $22{ }^{\circ} \mathrm{C}$. Cumulative $\mathrm{CO}_{2}$ evolution at 2,12 and $22^{\circ} \mathrm{C}$ equaled 252, 619 and $905 \mathrm{mg} \mathrm{CO}_{2}$, respectively. A significant correlation $(P<0.001)$ was detected between cumulative $\mathrm{CO}_{2}$ evolution and tissue mass loss at all temperatures. $Q_{10} \mathrm{~s}$ for mass loss and $\mathrm{CO}_{2}$ evolution, which ranged from 1.19 to 3.95 , were higher for the lower temperature range $\left(Q_{10}(2-\right.$ $\left.\left.12^{\circ} \mathrm{C}\right)>Q_{10}\left(12-22^{\circ} \mathrm{C}\right)\right)$ in the Ovis samples and lower for the low temperature range $\left(Q_{10}\left(2-12{ }^{\circ} \mathrm{C}\right)<Q_{10}(12-\right.$ $\left.22^{\circ} \mathrm{C}\right)$ ) in the control samples. Metabolic quotient and the positive relationship between skeletal muscle tissue mass loss and cumulative $\mathrm{CO}_{2}$ evolution suggest that tissue decomposition was most efficient at $2{ }^{\circ} \mathrm{C}$. These phenomena may be due to lower microbial catabolic requirements at lower temperature.
\end{abstract}

Keywords: temperature, $\mathrm{Q}_{10}$, skeletal muscle tissue, burial, decomposition, $\mathrm{CO}_{2}$ evolution, microbial biomass, metabolic quotient, soil $\mathrm{pH}$

\section{Introduction}

The decomposition of organic resources in soil is vital to ecosystem function. Decomposition results in the release of carbon into the atmosphere as carbon dioxide $\left(\mathrm{CO}_{2}\right)$ as well as the mineralization of essential nutrients such as nitrogen $(\mathrm{N})$, phosphorus $(\mathrm{P})$ and sulfur $(\mathrm{S})$. The breakdown of most organic resources has been attributed to the activity of saprotrophic bacteria and fungi acting in conjunction with a variety of invertebrates (Swift et al., 1979). The activity of these organisms and thus, the rate of decomposition, can be affected by a number of factors such as temperature and resource quality.

Temperature can directly influence metabolic processes while affecting the soil microhabitat via changes in soil physicochemical properties (e.g. redox potential, soil volume) (Paul and Clark, 1996). In soils with a mesophilic microbial population an approximate doubling of activity is commonly associated with an increase of $10^{\circ} \mathrm{C}$ up to
30/35 ${ }^{\circ} \mathrm{C}$ (van't Hoff, 1898; Conant et al., 2004). Organic resource quality, such as $\mathrm{C}: \mathrm{N}$ ratio and phenol content, can determine the ease with which energy and nutrients are accessed by the decomposer community. Organic resources of high quality (i.e. low $\mathrm{C}: \mathrm{N}$ ratio) typically correspond with rapid rates of decomposition and increased metabolic activity (Dilly and Munch, 1996). However, resource quality can decrease as decomposition proceeds and this can be reflected by a widening of the $\mathrm{C}: \mathrm{N}$ ratio of the resource and a decrease in the metabolic activity of the decomposer population (Swift et al., 1979; Ajwa and Tabatabai, 1994).

In terrestrial ecosystems organic resources can enter the soil in the form of discrete patches such as seeds and animal cadavers. Numerous studies have been conducted in order to examine decomposition processes associated with plant-derived organic residues (Chander and Brookes, 1991; Hodge et al., 2000; Malpassi et al., 2000; Pérez-Harguindeguy et al., 2000; Coûteaux et al., 2002). However, relatively little work has focused on the decomposition of 
cadavers and cadaver components (e.g. skeletal muscle tissue, hair, bone) although animals regularly die in terrestrial ecosystems (DeVault et al., 2003). Of these studies, the vast majority are concerned with the activity of arthropods (e.g. Diptera, Coleoptera, Hymenoptera) (e.g. Payne, 1965; Kocárek, 2003) and vertebrate scavengers (e.g. Cornaby, 1974; Haglund, 1997) that participate in the decomposition of cadavers on the soil surface. As a result very little is understood about the microbially mediated decomposition processes that take place following the burial, in contrast to surface deposition, of a high quality nutrient patch such as a cadaver. In fact, the extent of current knowledge is limited to the understanding that soil microorganisms can display increased biomass (substrate-induced respiration) and activity $\left(\mathrm{CO}_{2}\right.$ respiration, $\mathrm{S}^{2-}$ reduction, $\mathrm{N}$ mineralization, denitrification) in association with buried cadavers (Sus scrofa) (Hopkins et al., 2000).

In the current study, we used mammalian skeletal muscle tissue as a high quality nutrient patch in soil. We aim to examine the effect of temperature on the decomposition of skeletal muscle tissue in soil. This work represents an initial attempt at constructing a model that may be used to understand the multifaceted processes associated with the decomposition of buried cadavers or complex resource patches of similarly high quality. A fundamental understanding of cadaveric decomposition can begin to be achieved by examining the breakdown of a relatively uniform organic source of nutrients and energy, such as skeletal muscle tissue in soil. To this end we tested the hypothesis that an increase in temperature will increase skeletal muscle tissue decomposition in soil at a $Q_{10}$ value of 2 . This was achieved through the measurement of skeletal muscle tissue mass loss, $\mathrm{CO}_{2}$ evolution, microbial biomass, soil $\mathrm{pH}$, and tissue $\mathrm{C}: \mathrm{N}$ ratio. In addition, microbial metabolic efficiency was evaluated by calculating metabolic quotient $\left(\mathrm{qCO}_{2}\right)$.

\section{Materials and methods}

\subsection{Soil and skeletal muscle tissue}

A sandy loam ( $61 \%$ sand, $18 \%$ silt, $21 \%$ clay) soil (Brown Earth) of the Fyfield series collected from Lindens farm, East Lulworth, Dorset, England (NGR SY 862208266) was sampled at $0-20 \mathrm{~cm}$ with a spade. Soil biophysicochemical characteristics of this soil have been previously reported including, organic C (2.1\%), microbial biomass C (347 $\mu \mathrm{g} \mathrm{g} \mathrm{g}^{-1}$ soil), total $\mathrm{N}(0.15 \%)$ and $\mathrm{pH}(6.4)$ (Tibbett et al., 2004). Organic texel+suffolk lamb (Ovis aries) skeletal muscle tissue was used as the organic resource. Organic skeletal muscle tissue was chosen in order to remove the affect of antibiotics in the tissues. Tissue samples were carefully selected due to the intrinsic heterogeneity of skeletal muscle tissue (Tortora and Grabowski, 2000). Skeletal muscle tissue lacking integument and visible fat was sampled from the leg and stored at $4{ }^{\circ} \mathrm{C}$ for $24 \mathrm{~h}$ prior to burial. Skeletal muscle tissue samples were then cut into cuboid pieces $(1.5 \mathrm{~g})$ in preparation for burial. This was conducted in a sterile laminar flow cabinet using a sterilized scalpel.

\subsection{Incubation of soil microcosms}

Field fresh soil was sieved (4.6 mm), weighed to $100 \mathrm{~g}$ (dry weight) and calibrated to $60 \%$ water holding capacity (WHC) inside sealable polyethylene bottles $(1285 \mathrm{ml}$, Merck Ltd, United Kingdom, product no. 215044808). These will be referred to as soil microcosms. Soil microcosms were placed in the dark at 2,12 or $22{ }^{\circ} \mathrm{C}$ for $48 \mathrm{~h}$ in order to equilibrate and were grouped according to replicate number. Following equilibration a skeletal muscle tissue sample $(1.5 \mathrm{~g})$ was buried in the soil at a depth of $2.5 \mathrm{~cm}$. Soil microcosms containing muscle tissue will be referred to as Ovis samples. The tissue burial procedure was also conducted in control samples (soil without tissue) in order to simulate the burial process and account for any effect caused by soil disturbance. The experiment was replicated six times. Each treatment was set-up with sufficient replicates for six sequential harvest events resulting in a total of 216 microcosms.

\subsection{Skeletal muscle tissue mass loss}

Skeletal muscle tissue samples were destructively harvested at intervals of 7 days over a period of 42 days (Tibbett et al., 2004). Following harvest, tissue was rinsed with distilled water, dried and weighed gravimetrically.

\subsection{Carbon dioxide evolution}

To determine the amount of $\mathrm{CO}_{2}$ respired from the soil and decomposing tissue, $10 \mathrm{ml}$ of sodium hydroxide $(\mathrm{NaOH})$ $(0.3 \mathrm{M})$ solution was placed in $20 \mathrm{ml}$ vials $\left(\mathrm{CO}_{2}\right.$ traps $)$ and suspended in the soil microcosms. The soil microcosms were then sealed. $\mathrm{CO}_{2}$ traps and the air in the soil microcosms were replaced at intervals of $24 \mathrm{~h}$ for a period of 42 days. The $\mathrm{NaOH}$ solution from the $\mathrm{CO}_{2}$ traps was back-titrated with $\mathrm{HCl}(0.1 \mathrm{M})$ into $10 \mathrm{ml} \mathrm{BaCl}(1.0 \mathrm{M})$ and six drops phenolphthalein as indicator (Rowell, 1994). A temperature coefficient $\left(Q_{10}\right)$ was used to assess the difference in biological activity at $10^{\circ} \mathrm{C}$ intervals.

\subsection{Microbial biomass $C$}

Soil microbial biomass $C\left(\mathrm{C}_{\text {mic }}\right)$ was estimated in soils harvested on day 21 and day 42 using the substrate induced respiration (SIR) technique (Anderson and Domsch, 1978) with some modifications by Lin and Brookes (1999): glucose was added to the soil in solution in order to calibrate the soil to $95 \%$ WHC. Soil water content can have a great effect on SIR rate (West and Sparling, 1986) and, therefore, $95 \%$ WHC was chosen to allow for the distribution of glucose throughout the soil matrix. No problems associated with the limitation on the availability of $\mathrm{O}_{2}$ were anticipated as a $110 \%$ WHC has been successfully used (Lin and Brookes, 1999). Preliminary testing demonstrated that the peak flush of microbial $\mathrm{CO}_{2}$ occurred after $2.5 \mathrm{~h}$ of incubation at $22{ }^{\circ} \mathrm{C}$. The glucose concentration that resulted in maximum $\mathrm{CO}_{2}$ evolution was $4 \mathrm{mg}$ glucose gram ${ }^{-1}$ soil. The soil was amended with glucose solution following tis- 
sue harvest and microbial biomass $\mathrm{C}\left(\mu \mathrm{g} \mathrm{C} \mathrm{g} \mathrm{g}^{-1}\right.$ soil $)$ was calculated after Anderson and Domsch (1978).

\subsection{Metabolic quotient $\left(q \mathrm{CO}_{2}\right)$}

The microbial metabolic quotient $\left(\mathrm{qCO}_{2}\right)$ was determined by dividing the $\mathrm{CO}_{2}$ evolution rate $\left(\mu \mathrm{g} \mathrm{CO}_{2}-\mathrm{C} \mathrm{g}^{-1}\right.$ dry soil $\left.\mathrm{h}^{-1}\right)$ by $\mathrm{C}_{\text {mic }}$ ( $\mathrm{mg} \mathrm{C}_{\text {mic }} \mathrm{g}^{-1}$ dry soil) (Dilly and Munch, 1998). The $\mathrm{CO}_{2}$ evolution rate from $24 \mathrm{~h}$ prior to the estimation of $\mathrm{C}_{\text {mic }}$ was used in the calculation. The value of $\mathrm{qCO}_{2}$ can be used to determine the efficiency with which $C$ is utilized by the soil microbial biomass (Dilly and Munch, 1998).

\subsection{Skeletal muscle tissue and soil analysis}

The $\mathrm{C}$ and $\mathrm{N}$ content of fresh tissue and tissue harvested at each temperature on day 35 was measured using dry combustion chromatography (Carlo-Erba EMASyst 1106). The $\mathrm{pH}$ of soil directly surrounding the tissue was measured on days 7, 14, 28 and 35 using a 1:2.5 soil:water (w:v) suspension.

\subsection{Statistical analysis}

Descriptive and inferential statistics were carried out using Microsoft Excel 2000 and SPSS 11.0.1, respectively. For data that passed preliminary tests for normality (KolmogorovSmirnov test) and homogeneity of variance (Levene's test) one-way ANOVAs were conducted comparing difference in both time and temperature for mass loss, $\mathrm{CO}_{2}$ evolution and soil $\mathrm{pH}$. For microbial $\mathrm{CO}_{2}$ evolution data, a repeated measures ANOVA was conducted; as this data met all the assumptions and experimental criteria for repeated measures analysis (Webster and Payne, 2002). Subsequently, skeletal muscle tissue mass loss, soil $\mathrm{pH}$ and $\mathrm{CO}_{2}$ respiration data were analyzed using Tukey's HSD post hoc test. Pearson's correlation coefficient and linear regression analysis was used to test for a relationship between skeletal muscle tissue mass loss and $\mathrm{CO}_{2}$ evolution. Where data did not pass the preliminary tests required for parametric analysis, non-parametric statistics were generated. MannWhitney $U$-tests were conducted for microbial biomass, $Q_{10} \mathrm{~s}, \mathrm{qCO}_{2}$ and C:N ratio data.

\section{Results}

\subsection{Skeletal muscle tissue mass loss}

A $10{ }^{\circ} \mathrm{C}$ increase in temperature resulted in increased skeletal muscle tissue mass loss at each harvest except on day 42 in samples incubated at 12 and $22{ }^{\circ} \mathrm{C}$ (Figure 1). Tissue samples incubated at 12 and $22{ }^{\circ} \mathrm{C}$ lost 60 and $80 \%$ of mass during the initial 14 days of burial. A loss of $20 \%$ of mass at $2{ }^{\circ} \mathrm{C}$ took place during the first 7 days of burial. These rapid rates of mass loss were followed by a more gradual rate of decomposition. The relationship between mass loss and time was described by a cubic regression equation (Figure 1). The mean $Q_{10}$ of tissue mass loss $\left(Q_{10}-\mathrm{ML}\right)$ between 2 and $12{ }^{\circ} \mathrm{C}$ at the end of the incubation (day 42) was greater than $Q_{10}-\mathrm{ML}\left(12-22^{\circ} \mathrm{C}\right)(P<0.05)($ Table 1$)$.

\subsection{Carbon dioxide evolution}

The burial of skeletal muscle tissue in soil incubated at 12 and $22{ }^{\circ} \mathrm{C}$ resulted in an immediate flush of $\mathrm{CO}_{2}$ evolution that peaked on day 2 (Figure 2(a)). This flush was not detected in Ovis samples incubated at $2{ }^{\circ} \mathrm{C}$. Instead, an immediate decrease in $\mathrm{CO}_{2}$ evolution followed by a gradual increase took place. The immediate decrease in $\mathrm{CO}_{2}$ evolution was analogous to the pattern of microbial activity in the control samples (Figure 2(a)). Ovis samples incubated at $22{ }^{\circ} \mathrm{C}$ generated $\mathrm{CO}_{2}$ at a greater rate than Ovis samples incubated at $12{ }^{\circ} \mathrm{C}$ until day 23 when both declined at a similar rate. By day 42 all Ovis samples evolved $\mathrm{CO}_{2}$ at an equal rate (Figure 2(a)). Carbon dioxide evolution in control samples incubated at $22{ }^{\circ} \mathrm{C}$ was greater than in control samples incubated at 2 and $12{ }^{\circ} \mathrm{C}$ (Figure 2(a)). Control samples incubated at $12{ }^{\circ} \mathrm{C}$ generated $\mathrm{CO}_{2}$ at a rate greater than control samples incubated at $2{ }^{\circ} \mathrm{C}$ every day except day 23, day 41 and day 42 .

A $10{ }^{\circ} \mathrm{C}$ increase in temperature resulted in an increase in cumulative $\mathrm{CO}_{2}$ evolution in Ovis and control samples (Figure 2(b)). The $Q_{10}-\mathrm{CO}_{2}$ in Ovis samples was greater between $2 \mathrm{C}$ and $12{ }^{\circ} \mathrm{C}$ than between 12 and $22^{\circ} \mathrm{C}$ (Table 1 ). Conversely, mean $Q_{10}-\mathrm{CO}_{2}$ in control samples was greater between 12 and $22^{\circ} \mathrm{C}$ than between 2 and $12{ }^{\circ} \mathrm{C}$.

Carbon dioxide accumulated in Ovis samples over intervals of 7 days was plotted as a function of tissue mass loss at intervals of 7 days (Figure 3). A significant correlation was detected between skeletal muscle tissue mass loss and cumulative $\mathrm{CO}_{2}$ evolution at $2{ }^{\circ} \mathrm{C}$ (Pearson's $R=0.803$; $P<0.001), 12{ }^{\circ} \mathrm{C}$ (Pearson's $R=0.728 ; P<0.001$ ) and $22{ }^{\circ} \mathrm{C}$ (Pearson's $R=0.749 ; P<0.001$ ) (Figure 3).

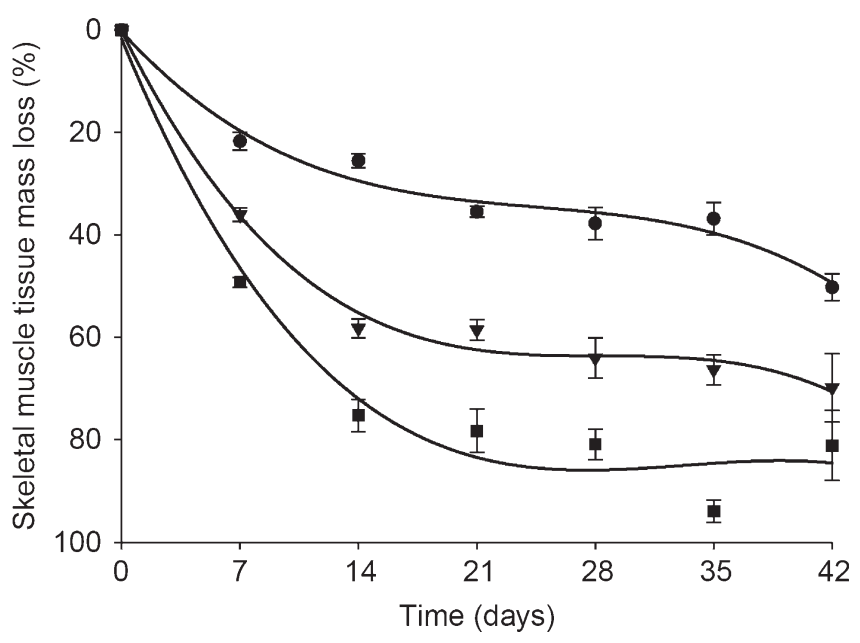

Figure 1. Mass loss of a $1.5 \mathrm{~g}$ cube of skeletal muscle tissue (Ovis aries) following burial $(2.5 \mathrm{~cm})$ in a sandy loam soil of the Fyfield Series from Lindens farm, East Lulworth, Dorset, England incubated at $2{ }^{\circ} \mathrm{C}(\bullet), 12{ }^{\circ} \mathrm{C}(\boldsymbol{\nabla})$, and $22{ }^{\circ} \mathrm{C}(\boldsymbol{\bullet})$. Curves represent cubic polynomial equation. Equations are as follows: $2{ }^{\circ} \mathrm{C} \quad\left(y=0.34+3.63 x+-0.14 x^{2}+0.002 x^{3} ; r^{2}=0.88\right) ; 12{ }^{\circ} \mathrm{C} \quad(y$ $\left.=0.27+6.66 x+-0.23 x^{2}+0.003 x^{3} ; r^{2}=0.90\right) ; 22^{\circ} \mathrm{C} \quad(y=1.77+$ $\left.8.0 x+-0.25 x^{2}+0.003 x^{3} ; r^{2}=0.91\right)$. Bars represent standard errors where $n=6$. 
Table 1. Temperature coefficients $\left(Q_{10}\right)$ of skeletal muscle tissue (Ovis aries) mass loss $\left(Q_{10}-\mathrm{ML}\right)$ and cumulative $C \mathrm{O}_{2}$ evolution $\left(Q_{10}-\mathrm{CO}_{2}\right)$ following the burial $(2.5 \mathrm{~cm})$ of a $1.5 \mathrm{~g}$ cube of skeletal muscle tissue in a sandy loam soil (100 $\mathrm{g}$ dry weight) of the Fyfield series from Lindens farm, East Lulworth, Dorset, England.

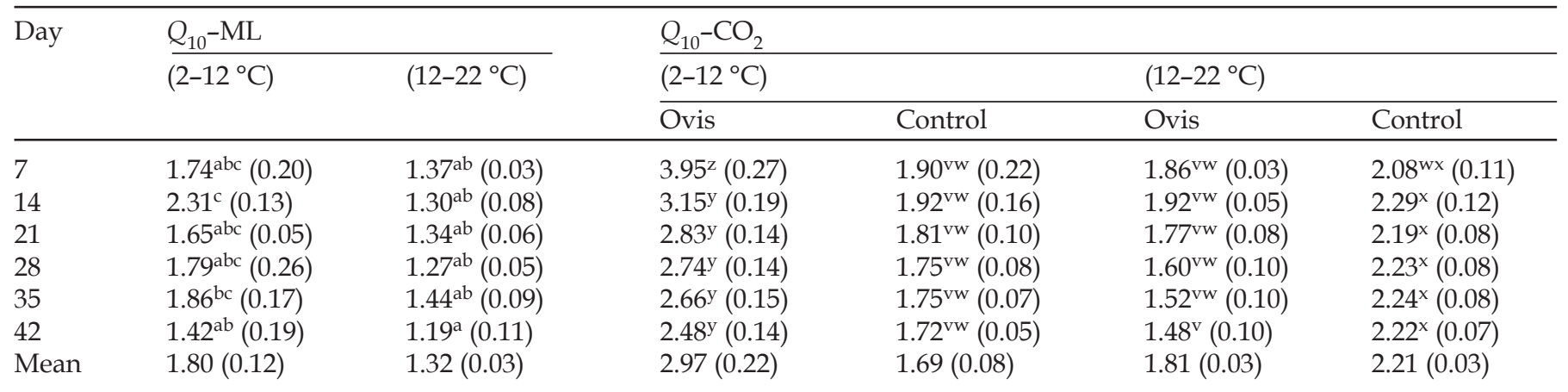

a, b, c denote differences $(P<0.05)$ in $Q_{10}-$ ML between temperature. $\mathrm{v}, \mathrm{w}, \mathrm{x}, \mathrm{y}, \mathrm{z}$ denote differences $(P<0.05)$ in $Q_{10}-\mathrm{CO}_{2}$ between temperature and tissue treatments. Standard errors are presented in brackets where $n=6$.

\subsection{Microbial biomass $C$}

Generally, greater $C_{\text {mic }}$ was detected in the Ovis samples. However, these concentrations were only significantly greater than control samples on day 21 at $22{ }^{\circ} \mathrm{C}(P<0.05)$ and day 42 at $12{ }^{\circ} \mathrm{C}(P<0.01)$ (Table 2). An increase in temperature also resulted in increased $C_{\text {mic }}$ but these differences
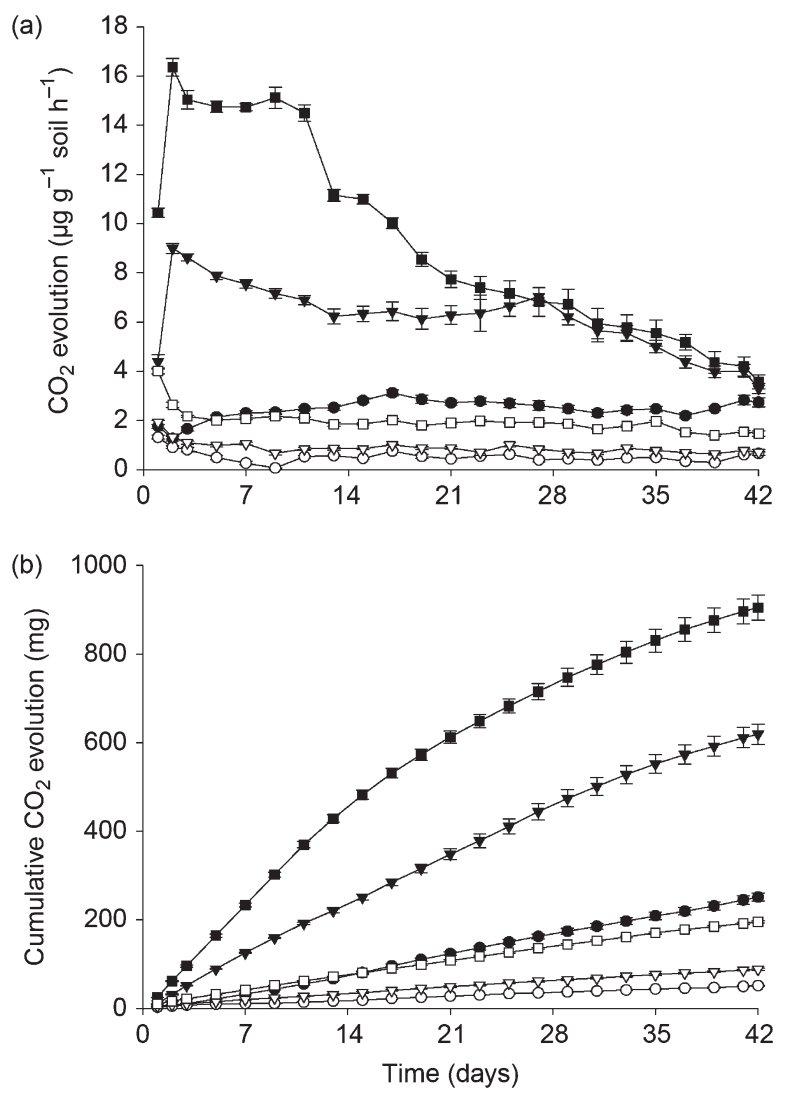

Figure 2. Daily (a) and cumulative (b) $\mathrm{CO}_{2}$ evolution following the burial $(2.5 \mathrm{~cm})$ of a $1.5 \mathrm{~g}$ cube of skeletal muscle tissue (Ovis aries) in a sandy loam soil of the Fyfield Series from Lindens farm, East Lulworth, Dorset, England incubated at $2{ }^{\circ} \mathrm{C}$ $(\bullet), 12{ }^{\circ} \mathrm{C}(\boldsymbol{\nabla})$, and $22{ }^{\circ} \mathrm{C}(\boldsymbol{\bullet})$. Unfilled symbols represent $\mathrm{CO}_{2}$ evolution in control (soil without tissue) samples. Bars represent standard errors where $n=6$. were not significant. All samples contained less $C_{\text {mic }}$ on day 42. This decrease was not significant.

Interestingly, the Ovis samples contained fungal hyphae on the soil surface directly above the buried tissue. In Ovis samples incubated at $22^{\circ} \mathrm{C}$ the hyphae became macroscopically observable from day 5 to day 10 . At $12{ }^{\circ} \mathrm{C}$ fungal hyphae were observed on the surface of the Ovis samples from day 9 to day 21 . At $2{ }^{\circ} \mathrm{C}$ the hyphae were observed from day 25 to the end of the incubation.

\subsection{Metabolic quotient $\left(q \mathrm{CO}_{2}\right)$}

Tissue burial resulted in an increased $\mathrm{qCO}_{2}$ (Table 2). On day $21 \mathrm{qCO}_{2}$ of Ovis samples incubated at 12 or $22^{\circ} \mathrm{C}$ was greater than in Ovis samples incubated at $2{ }^{\circ} \mathrm{C}$. The $\mathrm{qCO}_{2}$ of control samples on day 21 followed the pattern $22>12>$ $2{ }^{\circ} \mathrm{C}$. By day $42 \mathrm{qCO}_{2}$ had decreased in all samples. This decrease was significant $(P<0.05)$ in Ovis samples. Temperature did not affect the $\mathrm{qCO}_{2}$ of Ovis samples on day 42 (Ta-

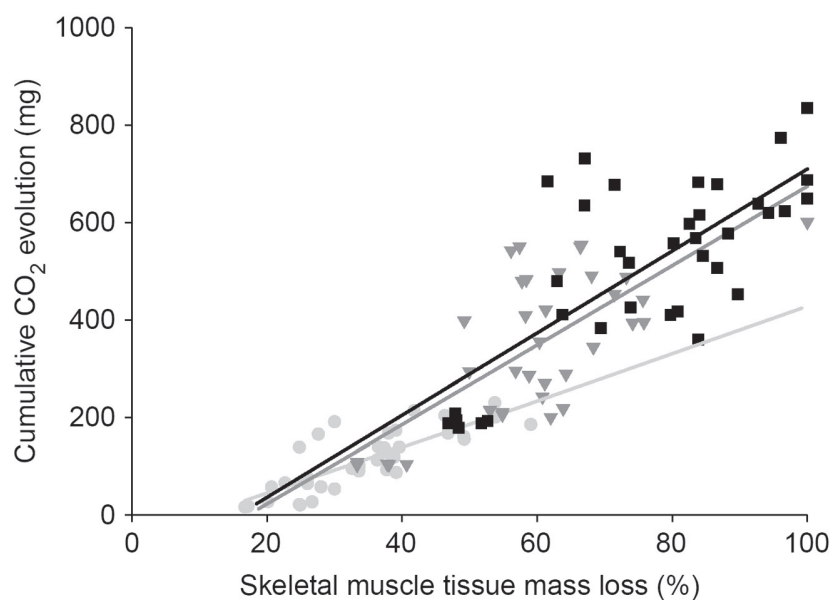

Figure 3. Correlation between $\mathrm{CO}_{2}$ evolution and skeletal muscle tissue (Ovis aries) mass loss following burial $(2.5 \mathrm{~cm})$ in a sandy loam soil of the Fyfield Series from Lindens farm, East Lulworth, Dorset, England incubated at $2{ }^{\circ} \mathrm{C}(\bullet), 12{ }^{\circ} \mathrm{C}$ $(\boldsymbol{\nabla})$, and $22^{\circ} \mathrm{C}(\boldsymbol{\nabla})$. Equations are as follows: $2^{\circ} \mathrm{C}(y=-49.49+$ $\left.4.71 x ; r^{2}=0.64\right) ; 12{ }^{\circ} \mathrm{C}\left(y=-140.41+8.15 x ; r^{2}=0.53\right) ; 22{ }^{\circ} \mathrm{C}(y=$ $\left.-131.24+8.41 x ; r^{2}=0.56\right)$. 
Table 2. Microbial biomass $\mathrm{C}\left(\mathrm{C}_{\text {mic }}\right)\left(\mu \mathrm{g} \mathrm{g}^{-1}\right.$ soil $)$ and metabolic quotient $\left(\mathrm{qCO}_{2}\right)\left(\mu \mathrm{g} \mathrm{CO} \mathrm{CO}_{2}-\mathrm{C} \mathrm{mg}^{-1} \mathrm{C}_{\text {mic }} \mathrm{h}^{-1}\right)$ in a sandy loam soil of the Fyfield series from Lindens farm, East Lulworth, Dorset, England following the burial $(2.5 \mathrm{~cm})$ of a $1.5 \mathrm{~g}$ cube of skeletal muscle tissue (Ovis aries) (Ovis) and without skeletal muscle tissue (control).

\begin{tabular}{lllll}
\hline Measure & $\begin{array}{l}\text { Temperature } \\
\left({ }^{\circ} \mathrm{C}\right)\end{array}$ & Sample & \multicolumn{2}{l}{ Day } \\
\cline { 4 - 5 } & 2 & Ovis & $781(47)$ & $646(44)$ \\
\hline $\mathrm{C}_{\text {mic }}$ & 2 & Control & $699(30)$ & $646(65)$ \\
& \multirow{2}{*}{12} & Ovis & $787(28)$ & $775(29)^{* *}$ \\
& 22 & Control & $717(25)$ & $693(18)$ \\
& 2 & Ovis & $852(17)^{*}$ & $810(34)$ \\
& \multirow{2}{*}{2} & Control & $764(11)$ & $758(33)$ \\
$\mathrm{qCO}_{2}$ & 2 & Ovis & $1.95(0.15)^{\mathrm{d}}$ & $1.20(0.14)^{\mathrm{c}}$ \\
& \multirow{2}{*}{12} & Control & $0.39(0.03)^{\mathrm{a}}$ & $0.29(0.05)^{\mathrm{a}}$ \\
& \multirow{2}{*}{22} & Ovis & $4.67(0.53)^{\mathrm{e}}$ & $1.15(0.08)^{\mathrm{c}}$ \\
& & Control & $0.70(0.08)^{\mathrm{b}}$ & $0.28(0.05)^{\mathrm{a}}$ \\
& & Ovis & $5.25(0.35)^{\mathrm{e}}$ & $1.20(0.10)^{\mathrm{c}}$ \\
& & Control & $1.35(0.05)^{\mathrm{c}}$ & $0.53(0.06)^{\mathrm{b}}$ \\
\hline
\end{tabular}

${ }^{*}(P<0.05)$ and ${ }^{* *}(P<0.010)$ represent differences in $C_{\text {mic }}$ within temperature treatments. Letters represent differences $(P<0.05)$ in $\mathrm{qCO}_{2}$ between treatments. Standard errors are presented in brackets where $n=6$.

ble 2). On day 42 the $\mathrm{qCO}_{2}$ of control samples incubated at $22{ }^{\circ} \mathrm{C}$ was greater than the $\mathrm{qCO}_{2}$ of control samples incubated at 2 and $12^{\circ} \mathrm{C}$ (Table 2 ).

\subsection{Skeletal muscle tissue and soil analysis}

The C:N ratio of fresh, unburied skeletal muscle tissue was 5.5:1 ( \pm 0.4$)$. On day 35 the $\mathrm{C}: \mathrm{N}$ ratio of tissue became wider with each $10{ }^{\circ} \mathrm{C}$ increase in temperature $\left(2,12\right.$ and $22{ }^{\circ} \mathrm{C}$ was 3.8:1 $( \pm 0.1), 5.8: 1( \pm 0.2)$, and 12.3:1 ( \pm 1.8$)$, respectively).

Tissue burial resulted in an increase in soil $\mathrm{pH}$ from 6.4 to a maximum of 7.9 (Figure 4). The speed of $\mathrm{pH}$ change was related to temperature with higher temperatures resulting in more rapid change. Soil $\mathrm{pH}$ in Ovis samples at $22{ }^{\circ} \mathrm{C}$ began to decline after day 14 . The $\mathrm{pH}$ of Ovis soils incubated at $2{ }^{\circ} \mathrm{C}$ increased until day 35 when it reached 7.9. A similar $\mathrm{pH}$ was detected on day 14 in Ovis samples incubated at $12{ }^{\circ} \mathrm{C}$. The $\mathrm{pH}$ of control samples did not significantly change during the incubation.

\section{Discussion}

The decomposition of skeletal muscle tissue was characterized by an increase in $\mathrm{CO}_{2}$ evolution and an initial period (7-14 days) of rapid mass loss. These phenomena were apparently regulated by temperature and are similar to the decomposition dynamics of other organic nutrient patches of high quality such as earthworm residues (Hodge et al., 2000), sewage sludge (Clark and Gilmour, 1983; Díaz-Burgos et al., 1993; Ajwa and Tabatabai, 1994), manure (Ajwa and Tabatabai, 1994) and plant material (Dilly and Munch, 1996). At 12 and $22{ }^{\circ} \mathrm{C}$ the rate of mass loss and $\mathrm{CO}_{2}$ evolution slowed following the initial period of rapid decomposition. This is likely due to a decrease in readily available nutrients (Ajwa and Tabatabai, 1994) after an initial flush of microbial activity based on a zymogenous response to highly decom-

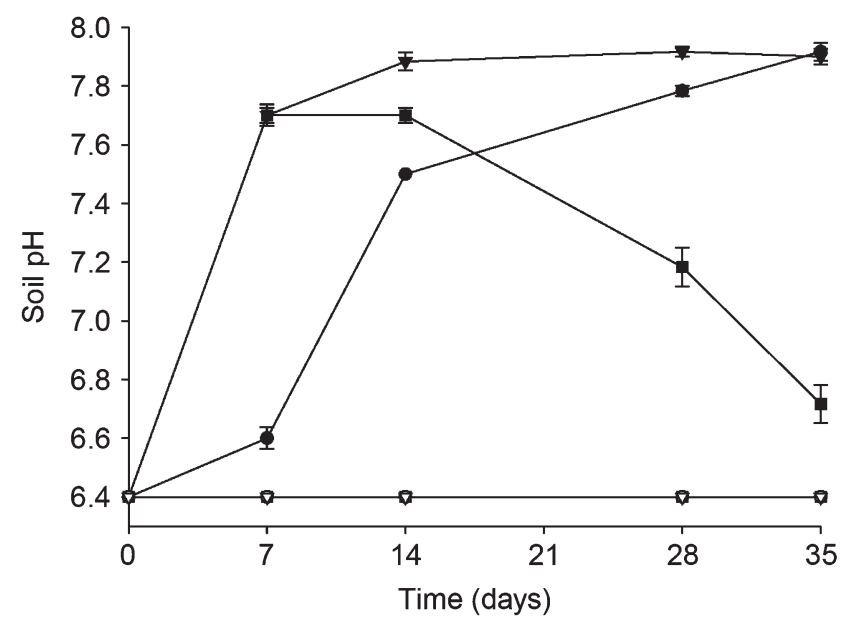

Figure 4. Soil $\mathrm{pH}$ following the burial $(2.5 \mathrm{~cm})$ of a $1.5 \mathrm{~g}$ cube of skeletal muscle tissue (Ovis aries) in a sandy loam soil of the Fyfield series from Lindens farm, East Lulworth, Dorset, England incubated at $2{ }^{\circ} \mathrm{C}(\bullet), 12{ }^{\circ} \mathrm{C}(\boldsymbol{\nabla})$, and $22^{\circ} \mathrm{C}(\boldsymbol{\bullet})$. Unfilled symbols represent soil $\mathrm{pH}$ in control (soil without tissue) samples. Soil pH was not measured on day 21. Bars represent standard errors where $n=6$.

posable substrates such as blood and free proteins (Ajwa and Tabatabai, 1994). This is reflected by a widening of the $\mathrm{C}: \mathrm{N}$ ratio of tissue buried at $22{ }^{\circ} \mathrm{C}$ and, although there was no significant change in $\mathrm{C}: \mathrm{N}$ ratio, a decrease in the percentage of $C$ and $N$ (data not shown) in tissue samples incubated at $12{ }^{\circ} \mathrm{C}$. The shorter period of rapid mass loss and lack of an immediate flush of $\mathrm{CO}_{2}$ at $2{ }^{\circ} \mathrm{C}$ (also displayed in control samples) has been previously observed in a temperate soil incubated at a psychotrophic temperature $\left(4^{\circ} \mathrm{C}\right)$ (Winkler et al., 1996). These characteristics may reflect the inability of a mesotrophic population to immediately access nutrients at a low temperature. This may be due to the inhibition of the expression of hydrolytic enzymes responsible for the catalysis of compounds containing organic N (Frankenberger and Tabatabai, 1991) and might also explain the increase in the C:N ratio of tissue buried at $2{ }^{\circ} \mathrm{C}$. The gradual increase in $\mathrm{CO}_{2}$ evolution following tissue burial at $2{ }^{\circ} \mathrm{C}$ is consistent with that shown for the decomposition of a readily available nutrient source (holocellulose) at low temperature $\left(4^{\circ} \mathrm{C}\right)(\mathrm{Nico}-$ lardot et al., 1994) and, along with the mass loss and $\mathrm{CO}_{2}$ data at mesotrophic temperatures, supports the idea that the soil microbial biomass can utilize skeletal muscle tissue as a source of nutrients and energy during early stages of cadaveric decomposition.

We accept the hypothesis that an increase in temperature will increase skeletal muscle tissue decomposition in soil at a $Q_{10}$ relationship of two based on $Q_{10}-\mathrm{ML}\left(2-12^{\circ} \mathrm{C}\right)$ and $Q_{10}-\mathrm{CO}_{2}\left(12-22^{\circ} \mathrm{C}\right)$ data. However, $Q_{10}-\mathrm{ML}\left(12-22^{\circ} \mathrm{C}\right)$ was approximately 1.3 and $Q_{10}-\mathrm{CO}_{2}\left(2-12{ }^{\circ} \mathrm{C}\right)$ was closer to three. These results show that low temperature induced a low microbial energy requirement for catabolism. Interestingly, $Q_{10}-\mathrm{CO}_{2}$ in control samples showed the opposite trend (i.e. increase of $Q_{10}-\mathrm{CO}_{2}$ with increase in temperature). This might mean that respiration was limited at low temperature either due to nutrient availability and/or the cold-induced repression of hydrolytic enzymes involved in 
decomposition. Both of these trends have been previously observed (Kirschbaum, 1995; Winkler et al., 1996; Reichstein et al., 2000; Conant et al., 2004). The $Q_{10}-\mathrm{ML}$ ranged from 1.19 to 2.31 , which is similar to the influence of temperature on the decomposition of plant litter in several terrestrial ecosystems (Andren and Paustian, 1987; Gholz et al., 2000; Coûteaux et al., 2002). A change in the quality of the nutrient patch would account for the decrease of $Q_{10}$ s over time. Readily available nutrients were likely utilized at a greater rate at high temperature. Thus, a greater amount of available nutrients would be present at lower temperatures for a longer period of time and the lower $Q_{10} \mathrm{~S}$ observed would be expected if process rates positively correlate to available nutrients (see Winkler et al., 1996).

Skeletal muscle tissue represented a high quality nutrient patch capable of supporting the growth of the soil microbial biomass at mesotrophic temperatures. This is not surprising considering that the soil microbial biomass can act as a sensitive indicator of change in nutrient status and temperature (Wardle, 1992). It is important to note that the use of SIR on soil subjected to organic amendments can lead to an overestimation of $C_{\text {mic }}$ (Sparling et al., 1981). However, the clear temperature effect and the increase in $\mathrm{C}_{\text {mic }}$ associated with skeletal muscle tissue of relatively low quality after 42 days of burial at $12{ }^{\circ} \mathrm{C}$ leads to the belief that the observed increases in $\mathrm{C}_{\text {mic }}$ are accurate.

Metabolic quotient has previously been used to indicate the efficiency in which organic $C$ is utilized by the soil microbial biomass (Anderson and Domsch, 1990; Dilly and Munch, 1998). Increased $\mathrm{qCO}_{2}$ at 12 and $22{ }^{\circ} \mathrm{C}$ represented a less efficient utilization of C (Dilly and Munch, 1998). Using $\mathrm{qCO}_{2}$ one would conclude that incubation at $2{ }^{\circ} \mathrm{C}$ resulted in the most efficient tissue decomposition. An alternative assessment of tissue decomposition efficiency is the relationship between $\mathrm{CO}_{2}$ evolved and tissue mass loss. Tissue mass loss is significantly correlated $(P<0.001)$ to $\mathrm{cu}-$ mulative $\mathrm{CO}_{2}$ evolution at all temperatures and a reduced slope at $2{ }^{\circ} \mathrm{C}$ supports the concept that temperature reduced the rate of decomposition and increased the associated metabolic efficiency.

Although the soil microbial biomass includes bacteria, fungi, yeasts, algae, protozoa (Sakamoto and Oba, 1994; Savin et al., 2001) the current experimental design requires the soil microbial biomass to be regarded as a single entity. However, the proliferation of fungal hyphae in association with skeletal muscle tissue was an interesting observation. This increase in fungal biomass was similar to that in association with N-rich alfalfa meal, in contrast to N-poor wheat straw or starch (Mamilov et al., 2001). The macroscopic presence of fungi, particularly fruiting structures, in intimate association with cadaveric decay has been reported in many regions around the world (Tibbett and Carter, 2003). These fungi are known as postputrefaction fungi (Sagara, 1995) or taphonomic mycota (Carter and Tibbett, 2003) and tend to fruit in a successional sequence due, in part, to the availability and form of $\mathrm{N}$ (e.g. $\mathrm{NH}_{4}{ }^{+}$, $\mathrm{NO}_{3}{ }^{-}$) (Tibbett and Carter, 2003). While it is unknown if the hyphae observed in the current study represented recognized postputrefaction fungi, it is important to note the significant effect that temperature had on the proliferation and persistence of the hyphae as well as the growth of the soil microbial population in general.

It has long been known that cadaver decomposition can result in increased soil pH (Reed, 1958) and this has been attributed to an accumulation of $\mathrm{NH}_{4}^{+}$(Hopkins et al., 2000). In addition, $\mathrm{C}$ and $\mathrm{N}$ mineralization liberates acids $\left(\mathrm{H}_{2} \mathrm{CO}_{3}, \mathrm{HNO}_{3}\right)$ and massive $\mathrm{C}$ mineralization can result in anaerobic micro-sites inducing low redox potential and increasing $\mathrm{pH}$ values. However, few studies have measured soil $\mathrm{pH}$ over the course of cadaveric decomposition (Vass et al., 1992). The decrease in $\mathrm{pH}$ of soils in the Ovis samples incubated at $22{ }^{\circ} \mathrm{C}$ during the latter stages of the incubation could be the result of the soil reverting back to its natural $\mathrm{pH}$ because of the utilization of base cations by the soil microbiota. This fall in $\mathrm{pH}$ is in keeping with more complete decomposition at the higher temperature and is similar to findings from related research (Vass et al., 1992). The patterns of $\mathrm{pH}$ change observed in the absence of an enteric flora suggest that the soil microbial biomass may have contributed to the changes in $\mathrm{pH}$ observed in the presence of whole cadavers in other studies (Rodriguez and Bass, 1985; Vass et al., 1992; Hopkins et al., 2000).

The current results show that skeletal muscle tissue can be immediately used as a source of nutrients by the soil microbial biomass and this utilization can be greatly affected by temperature. There was an apparent "temporal wave" throughout our data that represented the slowing down of decomposition processes at lower temperatures. Where peaks or differences in skeletal muscle tissue mass loss, $\mathrm{CO}_{2}$ evolution, $\mathrm{C}_{\text {mic }^{\prime}} \mathrm{pH}$ and the macroscopic presence of fungal hyphae occurred at $22^{\circ} \mathrm{C}$ at one sample period, they would occur at later sample periods in lower temperature incubations. However, the effects were more subtle than a uniform slowing down of process rates because apparent changes to the metabolic function of the microbial population also occurred. It is currently unknown if these patterns would apply to a complete cadaver with its enteric microflora and numerous components such as skin, bone and hair. Regardless, carnivore and herbivore cadavers represent sources of sequestered nutrients and much more detailed work is required to understand the processes associated with the transfer of energy and nutrients from the herbivore subsystem to the decomposer subsystem.

Acknowledgments - We would like to thank T. Haslam, R. Haslam, and R. Major for assistance with method development. We are very grateful to $\mathrm{M}$. Smith for technical assistance and A. Diaz for assistance with statistical analysis. We also thank M. Cox and P. Cheetham for informative discussions at the inception of this work.

\section{References}

Ajwa and Tabatabai, $1994 \cdot$ H. A. Ajwa and M. A. Tabatabai, Decomposition of different organic materials in soils, Biology and Fertility of Soils $\mathbf{1 8}$ (1994), pp. 175-182.

Anderson and Domsch, 1978 • J. P. E. Anderson and K. H. Domsch, A physiological method for the quantitative measurement of microbial biomass in soils, Soil Biology \& Biochemistry 10 (1978), pp. 215-221. 
Anderson and Domsch, 1990 • T.-H. Anderson and K. H. Domsch, Application of eco-physiological quotients $\left(q \mathrm{CO}_{2}\right.$ and $\left.q \mathrm{D}\right)$ on microbial biomasses from soils of different cropping histories, Soil Biology $\mathcal{E}$ Biochemistry 22 (1990), pp. 251-255.

Andren and Paustian, 1987 • O. Andren and K. Paustian, Barley straw decomposition in the field: A comparison of models, Ecology 68 (1987), pp. 1190-1200.

Carter and Tibbett, 2003 - D. O. Carter and M. Tibbett, Taphonomic mycota: Fungi with forensic potential, Journal of Forensic Sciences 48 (2003), pp. 168-171.

Chander and Brookes, 1991 - K. Chander and P. C. Brookes, Microbial biomass dynamics during the decomposition of glucose and maize in metal-contaminated and non-contaminated soils, Soil Biology $\mathcal{E}$ Biochemistry 23 (1991), pp. 917-925.

Clark and Gilmour, 1983 - M. D. Clark and J. T. Gilmour, The effect of temperature on decomposition at optimum and saturated soil water contents, Soil Science Society of America Journal 47 (1983), pp. 927-929.

Conant et al., 2004 • R. T. Conant, P. Dalla-Betta, C. C. Klopatek, and J. M. Klopatek, Controls on soil respiration in semiarid soils, Soil Biology $\mathcal{E}$ Biochemistry 36 (2004), pp. 945-951.

Cornaby, 1974 - B. W. Cornaby, Carrion reduction by animals in contrasting tropical habitats, Biotropica 6 (1974), pp. 51-63.

Coûteaux et al., 2002 • M. -M. Coûteaux, A. Aloui, and C. Kurz-Besson, Pinus halepensis litter decomposition in laboratory microcosms as influenced by temperature and a millipede, Glomeris marginata, Applied Soil Ecology 20 (2002), pp. 85-96.

DeVault et al., 2003 • T. L. DeVault, O. E. Rhodes, and J. A. Shivik, Scavenging by vertebrates: Behavioral, ecological and evolutionary perspectives on an important energy transfer pathway in terrestrial ecosystems, Oikos 102 (2003), pp. 225-234.

Díaz-Burgos et al., 1993 - M. A. Díaz-Burgos, B. Ceccanti, and A. Polo, Monitoring biochemical activity during sewage sludge composting, $\mathrm{Bi}$ ology and Fertility of Soils 16 (1993), pp. 145-150.

Dilly and Munch, 1996 • O. Dilly and J.-C. Munch, Microbial biomass content, basal respiration and enzyme activities during the course of decomposition of leaf litter in a black alder (Alnus glutinosa (L.) Gaertn.) forest, Soil Biology E Biochemistry 28 (1996), pp. 1073-7081.

Dilly and Munch, 1998 - O. Dilly and J.-C. Munch, Ratios between estimates of microbial biomass content and microbial activity in soils, Biology and Fertility of Soils (1998), pp. 374-379.

Frankenberger and Tabatabai, 1991 - W. T. Frankenberger Jr. and M. A. Tabatabai, 1-Asparaginase activity of soils, Biology and Fertility of Soils 11 (1991), pp. 6-12.

Gholz et al., 2000 - H. L. Gholz, D. A. Wedin, S. M. Smitherman, M. E. Harmon, and W. J. Parton, Long-term dynamics of pine and hardwood litter in contrasting environments: Toward a global model of decomposition, Global Change Ecology 6 (2000), pp. 751-765.

Haglund, 1997 - W. D. Haglund, Dogs and coyotes: Postmortem involvement with human remains. In: W. D. Haglund and M. H. Sorg, Editors, Forensic Taphonomy: The Postmortem Fate of Human Remains, CRC Press, Boca Raton, FL (1997), pp. 367-382.

Hodge et al., 2000 - A. Hodge, B. A. Stewart, D. Robinson, B. S. Griffiths, and A. H. Fitter, Plant N capture and microfaunal dynamics from decomposing grass and earthworm residues in soil, Soil Biology $\mathcal{E}$ Biochemistry 32 (2000), pp. 1763-1772.

Hopkins et al., 2000 • D. W. Hopkins, P. E. J. Wiltshire, and B. D. Turner, Microbial characteristics of soils from graves: An investigation at the interface of soil microbiology and forensic science, Applied Soil Ecology 14 (2000), pp. 283-288.

Kirschbaum, 1995 • M. U. F. Kirschbaum, The temperature dependence of soil organic matter decomposition and the effect of global warming on soil organic C storage, Soil Biology E Biochemistry 27 (1995), pp. 753-760.

Kocárek, 2003 • P. Kocárek, Decomposition and Coleoptera succession on exposed carrion of small mammal in Opava, Czech Republic, European Journal of Soil Biology 39 (2003), pp. 31-45.

Lin and Brookes, $1999 \cdot$ Q. Lin and P. C. Brookes, An evaluation of the substrate-induced respiration method, Soil Biology \& Biochemistry 31 (1999), pp. 1969-1983.

Malpassi et al., 2000 - R. N. Malpassi, T. C. Kaspar, T. B. Parkin, C. A. Cambardella, and N. A. Nubel, Oat and rye root decomposition effects on nitrogen mineralization, Soil Science Society of America Journal 64
(2000), pp. 208-215.

Mamilov et al., 2001 - A. S. Mamilov, B. A. Byzov, D. G. Zvyagintsev, and O. M. Dilly, Predation on fungal and bacterial biomass in a soddy-podzolic soil amended with starch, wheat straw and alfalfa meal, Applied Soil Ecology 16 (2001), pp. 131-139.

Nicolardot et al., 1994 • B. Nicolardot, G. Fauvet, and D. Cheneby, Carbon and nitrogen cycling through soil microbial biomass at various temperatures, Soil Biology E Biochemistry 26 (1994), pp. 253-261.

Paul and Clark, 1996 - E. A. Paul and F. E. Clark, Soil Microbiology and Biochemistry (second ed.), Academic Press, San Diego, CA (1996).

Payne, 1965 - J. A. Payne, A summer carrion study of the baby pig Sus scrofa Linnaeus, Ecology 46 (1965), pp. 592-602.

Pérez-Harguindeguy et al., 2000 • N. Pérez-Harguindeguy, S. Díaz, J. H. C. Cornelissen, F. Vendramini, M. Cabido, and A. Castellanos, Chemistry and toughness predict leaf litter decomposition rates over a wide spectrum of functional types and taxa in central Argentina, Plant and Soil 218 (2000), pp. 21-30.

Reed, 1958 - H. B. Reed, A study of dog carcass communities in Tennessee, with special reference to the insects, American Midland Naturalist 59 (1958), pp. 213-245.

Reichstein et al., 2000 - M. Reichstein, F. Bednorz, G. Broll, and T. Kätterer, Temperature dependence of carbon mineralization: Conclusions from a long-term incubation of subalpine soil samples, Soil Biology $\mathcal{E}$ Biochemistry 32 (2000), pp. 947-958.

Rodriguez and Bass, 1985 - W. C. Rodriguez and W. M. Bass, Decomposition of buried bodies and methods that may aid in their location, Journal of Forensic Sciences 30 (1985), pp. 836-852.

Rowell, 1994 - D. L. Rowell, Soil Science: Methods and Applications, Longman, Harlow (1994)

Sagara, 1995 - N. Sagara, Association of ectomycorrhizal fungi with decomposed animal wastes in forest habitats: A cleaning symbiosis?, Canadian Journal of Botany 73 (1995) (Suppl. 1), pp. S1423-S1433.

Sakamoto and Oba, 1994 - K. Sakamoto and Y. Oba, Effect of fungal to bacterial biomass ratio on the relationship between $\mathrm{CO}_{2}$ evolution and total microbial biomass, Biology and Fertility of Soils 17 (1994), pp. 39-44.

Savin et al., 2001 • M. C. Savin, J. H. Görres, D. A. Neher, and J. A. Amador, Uncoupling of carbon and nitrogen mineralization: Role of microbivorous nematodes, Soil Biology $\mathcal{E}$ Biochemistry 33 (2001), pp. 1463-1472.

Sparling et al., 1981 • G. P. Sparling, B. G. Ord, and D. Vaughan, Microbial biomass and activity in soils amended with glucose, Soil Biology $\mathcal{E}$ Biochemistry 13 (1981), pp. 99-104.

Swift et al., 1979 • M. J. Swift, O. W. Heal, and J. M. Anderson, Decomposition in Terrestrial Ecosystems, Blackwell Scientific, Oxford (1979).

Tibbett and Carter, 2003 - M. Tibbett and D. O. Carter, Mushrooms and taphonomy: The fungi that mark woodland graves, Mycologist 17 (2003), pp. 20-24.

Tibbett et al., 2004 - M. Tibbett, D. O. Carter, T. Haslam, R. Major, and R. Haslam, A laboratory incubation method for determining the rate of microbiological degradation of skeletal muscle tissue in soil, Journal of Forensic Sciences 49 (2004), pp. 560-565

Tortora and Grabowski, 2000 - G. J. Tortora and S. R. Grabowski, Principles of Anatomy and Physiology (ninth ed.), Wiley, New York (2000).

van't Hoff, 1898 - J. H. van't Hoff, Lectures on Theoretical and Physical Chemistry. Part 1. Chemical Dynamics, Edward Arnold, London (1898).

Vass et al., 1992 - A. A. Vass, W. M. Bass, J. D. Wolt, J. E. Foss, and J. T. Ammons, Time since death determinations of human cadavers using soil solution, Journal of Forensic Sciences 37 (1992), pp. 1236-1253.

Wardle, 1992 - D. A. Wardle, A comparative assessment of factors which influence microbial biomass carbon and nitrogen levels in soil, Biological Reviews 67 (1992), pp. 321-358.

Webster and Payne, 2002 - R. Webster and R. W. Payne, Analysing repeated measurements in soil monitoring and experimentation, European Journal of Soil Science 53 (2002), pp. 1-13.

West and Sparling, 1986 - A. W. West and G. P. Sparling, Modifications to the substrate-induced respiration method to permit measurement of microbial biomass in soils of differing water contents, Journal of Microbiological Methods 5 (1986), pp. 177-189.

Winkler et al., 1996 • J. P. Winkler, R. S. Cherry, and W. H. Schlesinger, The $\mathrm{Q}_{10}$ relationship of microbial respiration in a temperate forest soil, Soil Biology E Biochemistry 28 (1996), pp. 1067-1072. 
